

\section{The Role of Monetary Policy Announcements on Turkish Banks' Stock Returns}

\author{
Nida Abdioğlu \\ Sinan Aytekin
}

\section{Introduction}

Investigation of the impact of monetary policy decisions on the financial markets has been an important topic both for the investors and policy makers. Investment decisions of financial market participants are affected by the results of monetary policy shocks on asset prices (Bohl et al., 2008). The effect of monetary policy on financial markets is accepted as the most direct and immediate effects of monetary policy decisions. In order to reach their goals, policy makers adjust economic behaviour by affecting asset prices and returns (Bernanke and Kuttner, 2005). Thus, to determine the association between asset returns and monetary policy is important for both policy makers and investors.

In this study, the monetary policy decisions of the Central Bank of the Republic of Turkey (CBRT) and their effects on stock returns of 12 Turkish deposits banks listed in Borsa Istanbul are examined. We distinguish this study from the existing literature by investigating our hypothesis in a crisis year (2008) and in a year with new monetary policy environment (2012). Second contribution of this study is to examine the hypothesis for Turkish banks. After 2010, monetary policy committee of the CBRT interfere in market mechanism by applying a new monetary policy in order to reduce macro financial risks. The aim of the CBRT was to apply inflation at low and stable level. Turkey had to change its monetary policy after 2008 financial crisis. Although the interest rates in developed countries decreased after the crisis, the interest rates in developing countries were relatively high and the economic growth predictions were strong. As a result, the emerging markets attracted the liquidity from developed markets. This resulted in a new period in Turkey which applied a monetary policy mix that includes interest rate corridor, reserve requirements and a liquidity policy (Kucukkocaoglu, 2013). The change in interest rates with the new monetary policy should change the stock prices and returns. Following this idea, we choose 2012 to examine the stock returns after the monetary policy amendment.

The aim of this study is to investigate whether abnormal returns are obtained from the banks during the event window of monetary policy announcements. In other words, the efficiency of Turkish market is tested. "A market in which prices fully reflect available information is called as efficient market" (Fama, 1970). When new information enters into the efficient market, the prices are adopted to the new information. In an efficient market, the investors cannot obtain abnormal returns (Karan, 2013). In semi-strong form efficiency, prices reflect all publicly available information. Thus if the market is in semi-strong efficiency form, the announcement of monetary policy decisions to the public will not create abnormal returns. In other case, the announcement of these decisions will result in abnormal returns obtained by the investors.

Event study methodology is used in order to calculate abnormal returns in our testing period. Market model adjusted return is used to calculate expected returns of the banks. Cumulative abnormal returns for each month are reported. For 2008 significant abnormal returns are reported in March, April, May, June, July, August, September, November and December. When the event study is applied for 2012, it is found that except May and September the banks have significant cumulative abnormal returns. In some months, we report negative or positive cumulative abnormal returns for both of the years. Therefore, we conclude that Turkish market is not in a semi-strong efficiency form in 2008 and 2012. Monetary policy decisions of the CBRT impact the stock returns.

The rest of the study is organised as follows: Overview of the literature on the relation between monetary policy decisions and stock returns is provided in Section 2. Section 3 presents the data and methodology used in this study. In section 4, we report our empirical results. Finally, Section 5 provides the conclusion.

\section{Literature Review}

Several strands of the existing literature investigate the influence of monetary policy decisions on stock returns. While one set of studies focus on developed countries, another stream addresses this relation for developing countries. Patelis (1997) is among the studies which focus on a developed country. By using the monthly NYSE value-weighted excess stock returns, Patelis (1997) finds that Fed monetary policy shocks affect expected excess returns, but they have little impact on expected real returns. Jensen et al. (1996) use expected stock and bond returns for the period February 1954 through December 1992. They show that change in Fed monetary policy affects security returns. Rigobon and Sack (2004) investigate the impact of monetary policy on asset prices. They analyse the response of the short term interest rate to the stock market even when the stock market is endogenously reacting to the interest rate simultaneously. By considering this endogeneity issue, they report a decline in stock prices when short term interest rates increase. According to their results, the increase in three months interest rates results in declines in S\&P 500 Index and NASDAQ Index. Bernanke and Kuttner (2005) and Ehrmann and Fratzscher (2004) are among the studies which report a relation between monetary policy shocks and equity prices in the Unites States (US). Ehrmann et al. (2005) show that, changes in short term interest rates affect the equity markets in the US. In addition, compared to the US they report much more influence of bond yields and exchange rates on euro area short rates and equity markets. Bohl et al. (2008) investigate the impact of unexpected interest rate decisions of European Central Bank on European stock market returns. They report a negative relation between unexpected interest rate decisions and stock market performance. Scharler (2008) finds that monetary policy 
tightening causes higher nominal interest rates in the US. This increases the opportunity cost of holding stocks and decreases dividend payments. These factors reduce the stock prices. Kholodilin et al. (2009) examine the response of European stock markets to the monetary policy changes by the European Central Bank. They find that an increase in interest rate causes a decrease of the stock market on the announcement day of monetary policy shock.

Farka (2009) examines the effect of Fed monetary policy on the stock returns and their volatilities by taking into account the endogeneity, omitted variable biases and potential asymmetries because of the type of policy shocks and policy actions. They report a decrease in stock returns following an increase in the policy rates. Chulia et al. (2010) investigate the impact of federal fund target rate decisions on stock returns, volatilities and correlations. They conclude that the expected changes in target rate do not matter but surprises in the target rate change matter which is consistent with market efficiency. An increase in the target rate causes negative stock return within 5 minute after the announcement. The increase in the target rate also increases the stock volatility during the 60-minute window around the announcement. They explain another finding of their study as follows: "..we find that positive surprises in the target rate (bad news for stocks) trigger a stronger reaction in stock prices than negative surprises (good news for stocks)." (Chulia et al., 2010). Andersson (2010) examines the effect of monetary policy decision on bond and stock market volatility in the Euro area and in the US between 1999 and 2006. By using intraday data on the US and Euroarea bond and stock markets, they report an increase in intraday volatility at the time of the policy announcements by the two central banks. And this increase is more pronounced for the US market. Hussain (2011) investigates the influence of monetary policy announcements on European and the US stock index returns and volatilities. Both European and the US stock index returns and volatilities are affected by monetary policy surprises. He reports that the impact of monetary policy surprises on stock indexes is very quick and disappears within 5-10 minutes after the announcement. He also finds that volatilities of European stock indices are affected by European Central Bank press conference which contains information for market participants. Bomfim (2003) investigates the impact of preannouncement and news effect on monetary policy decisions on the US stock market for the period 1989 and 1998. They conclude that US market is quite prior to the policy announcements. Abnormally low conditional volatility proves this result.

Another stream of the literature focuses on developing countries and examines the impact of monetary policy decisions on stock returns. In this study, we investigate this relation for Turkish financial markets. There are some studies which report the impact of monetary policy decisions of the Central Bank of the Republic of Turkey on either the index returns or individual stock returns. Aktas et al. (2009) examine the impact of interest rate decisions of Central Bank on Istanbul Stock Exchange-100 Index (ISE-100), exchange rates and risk premium for the period 2001- 2008. They report an impact of interest rates changes on financial markets, especially on bond interest rates. However, they do not find a significant impact of policy changes on stock prices. Demiralp and Y1lmaz (2010) investigate the effect of monetary policy decisions of Central Bank of Turkey on capital markets between the period 2002 and 2009. They report that bond market behaves consistent with the efficient market hypothesis which states that financial markets react to expected policy actions prior to a policy announcement. But they do not find such an evidence for stock market. Duran et al. (2012) examine the impact of monetary policy decisions between 2005 and 2009 on ISE All, ISE 100, ISE 30, and the indices of manufacturing, services, trade, financial and IT sectors. They find that when policy rates increase, stock prices decrease and government bond yields with longer maturities increase. They conclude that the monetary policy transmission in Turkey is very similar to that in developed economies. Ibicioglu and Kapusuzoglu (2012) investigate the effect of policy interest rate decisions of CBRT on the decisions of share investors for the period 2002-2010. Put it differently, they analyse whether ISE is an efficient market of monetary policy. They analyse the changes in ISE National 100 index pre and post policy interest rates announcements. They do not find any impact of interest rate decisions on stock investors investing in ISE. Soylu et al. (2014) examine the impact of interest rate announcement of Central Bank on financial markets in the period between 2005 and 2013. They use data on BIST 30 Index, US Dollar/TRY and Euro/TRY exchange rates both spot and future daily return series. They find that the return of US Dollar /TRY exchange rate is negative on the announcement days. Their analyses also show that the interest rate announcements do not affect the return of BIST 30 Index and Euro/TRY exchange rate. Kucukkocaoglu et al. (2013) investigates the impact of monetary policy committee announcements on Turkish banks using GMM analyses. They report that increases in the policy rates result in declines in stock returns of the banks. In addition, domestic banks are most affected by policy changes. According to Kucukkocaoglu et al. (2013), the banks depend on money market funding and the banks which have large interest payments in their balance sheets respond more forcefully to the changes in monetary policy changes.

\section{Data and Methodology}

We include 12 deposit banks that are listed in Borsa Istanbul Banks Index (XBANK) in order to evaluate sensitivity of Deposit Banks' Cumulative Abnormal Returns (CAR) to monetary policy decisions. We use BIST DataStore database to collect data on Turkish deposit banks for the years 2008 and 2012. Banks used in our study are listed with AKBNK, ALNTF, DENIZ, FINBN, GARAN, HALKB, ISCTR, SKBNK, TEBNK, TEKST, VAKBN, YAKBNK codes in Borsa Istanbul. Event dates are collected from the website of the Central Bank of The Republic of Turkey. Table 1 shows the announcement days of monetary policy decisions in 2008 and 2012. 
Table 1: Event Days (Announcement Days of Monetary Policy Decisions)

\begin{tabular}{|l|l|}
\hline \multicolumn{2}{|c|}{ Event Days } \\
\hline 17.01 .2008 & 24.01 .2012 \\
\hline 14.02 .2008 & 21.02 .2012 \\
\hline 19.03 .2008 & 27.03 .2012 \\
\hline 17.04 .2008 & 18.04 .2012 \\
\hline 15.05 .2008 & 29.05 .2012 \\
\hline 16.06 .2008 & 21.06 .2012 \\
\hline 17.07 .2008 & 19.07 .2012 \\
\hline 14.08 .2008 & 16.08 .2012 \\
\hline 18.09 .2008 & 18.09 .2012 \\
\hline 22.10 .2008 & 18.10 .2012 \\
\hline 19.11 .2008 & 20.11 .2012 \\
\hline 18.12 .2008 & 18.12 .2012 \\
\hline
\end{tabular}

Source: Table complied by authors

In order to measure the abnormal returns we use event study methodology. An event study involves an empirical analysis of the reaction of the relation between an event and stock prices. An assumption of the event study is that the stock markets are efficient. Thus, the value relevance of an event can be estimated by the change in the stock returns of a firm. The event day $(t=0)$ in this study is announcement day of monetary policy decisions every month. The period that covers 5 days prior to the event day ( $\mathrm{t}=-5)$ and 5 days after the event day $(t=+5)$ is defined as testing period. Estimation period is between $t=-10$ and $t=-5$. Estimation period is chosen to calculate the expected returns of the banks in the absence of the event.

Natural logarithms of the stock returns are used in this study. In equation $1, \mathrm{R}_{\mathrm{jt}}$ is return of a particular bank's stock, $\mathrm{P}_{\mathrm{jt}}$ is the closing price of the bank at time $\mathrm{t}$ and $\mathrm{P}_{\mathrm{jt}-1}$ is closing price at time $\mathrm{t}-1$. We use equation 2 in order to calculate the return of the market. In this equation, $R_{m t}$ is return of the BIST100 index, $P_{m t}$ is the closing price of the index at time $t$ and $\mathrm{P}_{\mathrm{mt}-1}$ is the closing price of the index at time $t-1$.

$$
R_{j t}=\ln \left(P_{j t} / P_{j t-1}\right)
$$

$$
R_{m t}=\ln \left(P_{m t} / P_{m t-1}\right)
$$

Market model adjusted return is used in order to calculate the expected return. In equation $3, E\left(R_{j t}\right)$ is market model adjusted return and $\mathrm{R}_{\mathrm{mt}}$ is return of Borsa Istanbul-100 Index. We estimate the parameters of market model (alpha and beta) by linear regressions in the estimation period. By using this model, the relation between the stock's return and the market return is controlled. This increases the power of the statistical test by creating adjusted returns with lower standard errors.

$$
E\left(R_{j t}\right)=\alpha_{j}+\beta_{j}^{*} R_{m t}
$$

Average abnormal returns for each stock are calculated with equation 4 and cumulative abnormal returns (CAR) are calculated with equation 5. After abnormal returns are calculated $\left(E\left(\mathrm{u}_{\mathrm{j} t}\right)\right)$, the sum of it is divided by the number of companies and average abnormal return is calculated for each month. Sum of the abnormal returns is defined as cumulative abnormal returns. We aim to analyse whether any significant abnormal returns or cumulative abnormal returns are obtained during the testing period in any month.

$$
\begin{aligned}
& \overline{A R_{t}}=\frac{1}{N} \sum_{j=1}^{N} u_{j t} \text { where } E\left(u_{j t}\right)=R_{j t}-E\left(R_{j t}\right)(4) \\
& C A R_{T P}=\sum \overline{A R_{t}}
\end{aligned}
$$

As a last step, we test the null hypothesis which states that cumulative abnormal return is equal to zero. Rejecting the null in this case means the monetary policy decisions affect the stock returns and the Turkish financial market does not have semi-strong form efficiency so that investors can obtain abnormal returns from these stocks. In contrast, the financial market has semi-strong form efficiency and investors can not obtain abnormal returns if the null can not be rejected.

\section{Empirical Results}

24 monetary policy decisions of the Monetary Policy Committee for the years 2008 and 2012 are used in this study. Cumulative abnormal returns for each bank in each month are calculated. Table 2 shows the Cumulative Abnormal Returns (CAR) during the testing period in 2008. As it can be seen from the table, overall CAR values are positive on the event window $(-5,+5)$ in March, April, July and November. The CAR value is completely negative only in August. Other months' CAR values contain both positive and negative coefficients.

Table 2: Cumulative Abnormal Returns (CAR) During the Testing Period (2008)

\begin{tabular}{|c|c|c|c|c|c|c|}
\hline $\begin{array}{c}\text { Event } \\
\text { Wind } \\
\text { ow }\end{array}$ & $\begin{array}{c}\text { Janua } \\
\text { ry }\end{array}$ & $\begin{array}{c}\text { Februa } \\
\text { ry }\end{array}$ & March & April & May & June \\
\hline $\mathbf{- 5}$ & $-1,27 \%$ & $0,18 \%$ & $0,83 \%$ & $1,27 \%$ & $-1,13 \%$ & $0,05 \%$ \\
\hline $\mathbf{- 4}$ & $-1,40 \%$ & $-0,42 \%$ & $2,70 \%$ & $1,89 \%$ & $-0,46 \%$ & $-2,27 \%$ \\
\hline $\mathbf{- 3}$ & $-1,29 \%$ & $-1,48 \%$ & $3,66 \%$ & $3,50 \%$ & $-0,32 \%$ & $-2,26 \%$ \\
\hline $\mathbf{- 2}$ & $-1,97 \%$ & $-1,20 \%$ & $4,91 \%$ & $4,23 \%$ & $-0,64 \%$ & $-1,04 \%$ \\
\hline $\mathbf{- 1}$ & $-1,04 \%$ & $-0,14 \%$ & $6,56 \%$ & $4,61 \%$ & $0,43 \%$ & $-1,48 \%$ \\
\hline $\mathbf{0}$ & $-0,76 \%$ & $0,28 \%$ & $5,51 \%$ & $5,42 \%$ & $0,43 \%$ & $-3,15 \%$ \\
\hline $\mathbf{1}$ & $-0,56 \%$ & $-0,16 \%$ & $6,52 \%$ & $5,12 \%$ & $0,26 \%$ & $-3,01 \%$ \\
\hline $\mathbf{2}$ & $0,77 \%$ & $0,21 \%$ & $6,92 \%$ & $3,94 \%$ & $-1,22 \%$ & $-3,04 \%$ \\
\hline $\mathbf{3}$ & $1,23 \%$ & $0,50 \%$ & $6,57 \%$ & $4,44 \%$ & $-2,31 \%$ & $-1,72 \%$ \\
\hline
\end{tabular}




\begin{tabular}{|c|c|c|c|c|c|c|}
\hline 4 & $32 \%$ & $0,57 \%$ & $5,88 \%$ & $6,51 \%$ & $-3,13 \%$ & $-1,03 \%$ \\
\hline 5 & $30 \%$ & $1,10 \%$ & $5,51 \%$ & $6,66 \%$ & $-3,94 \%$ & $-1,54 \%$ \\
\hline $\begin{array}{c}\text { Event } \\
\text { Wind } \\
\text { ow }\end{array}$ & July & August & $\begin{array}{l}\text { Septe } \\
\text { mber }\end{array}$ & $\begin{array}{c}\text { Octob } \\
\text { er }\end{array}$ & $\begin{array}{l}\text { Nove } \\
\text { mber }\end{array}$ & $\begin{array}{c}\text { Decem } \\
\text { ber }\end{array}$ \\
\hline-5 & $0,34 \%$ & $-0,58 \%$ & $0,34 \%$ & $0,54 \%$ & $0,61 \%$ & $-0,14 \%$ \\
\hline-4 & $0,14 \%$ & $-4,25 \%$ & $0,19 \%$ & $0,31 \%$ & $1,95 \%$ & $1,39 \%$ \\
\hline-3 & $4,09 \%$ & $-7,83 \%$ & $0,75 \%$ & $0,64 \%$ & $4,14 \%$ & $-0,55 \%$ \\
\hline-2 & $4,89 \%$ & $-6,53 \%$ & $-0,80 \%$ & $0,40 \%$ & $6,88 \%$ & $-1,02 \%$ \\
\hline-1 & $6,94 \%$ & $-8,36 \%$ & $-0,79 \%$ & $0,66 \%$ & $7,06 \%$ & $-2,18 \%$ \\
\hline 0 & $20 \%$ & & $-2,34 \%$ & & $89 \%$ & $-3,12 \%$ \\
\hline 1 & ,36 & & $-2,29 \%$ & $\begin{array}{l}- \\
0,30 \% \\
\end{array}$ & $8,89 \%$ & $-2,57 \%$ \\
\hline 2 & $\begin{array}{l}12,79 \\
\% \\
\end{array}$ & $-\overline{10,70 \%}$ & $-0,91 \%$ & $\begin{array}{l}- \\
1,57 \%\end{array}$ & & $-2,09 \%$ \\
\hline 3 & $\begin{array}{l}13,52 \\
\%\end{array}$ & $\begin{array}{l} \\
12,53 \%\end{array}$ & $-1,53 \%$ & $\begin{array}{l} \\
2,21 \%\end{array}$ & \begin{tabular}{|l|}
10,63 \\
$\%$
\end{tabular} & $-2,03 \%$ \\
\hline 4 & $\begin{array}{l}14,64 \\
\% \\
\end{array}$ & $\begin{array}{l}- \\
16,54 \%\end{array}$ & $-1,88 \%$ & $1,12 \%$ & \begin{tabular}{|l}
$\begin{array}{l}12,97 \\
\%\end{array}$ \\
\end{tabular} & $-1,52 \%$ \\
\hline 5 & $\begin{array}{l}14,21 \\
\%\end{array}$ & $\begin{array}{l}- \\
20,61 \%\end{array}$ & $-2,66 \%$ & $2,09 \%$ & $\begin{array}{l}15,81 \\
\%\end{array}$ & $-1,45 \%$ \\
\hline
\end{tabular}

Source: Table complied by authors

Figure 1 represents the graphs of Cumulative Abnormal Returns (CAR) in 2008. It is seen from Figure1 that, cumulative abnormal returns generally do not continuously decrease or increase before or after the event days. CAR values steadily increase after the event day only in November. When we take into account the days prior to the event days, we report that CAR values steadily increase in March, April and November. Other months' CAR values show a fluctuating structure.

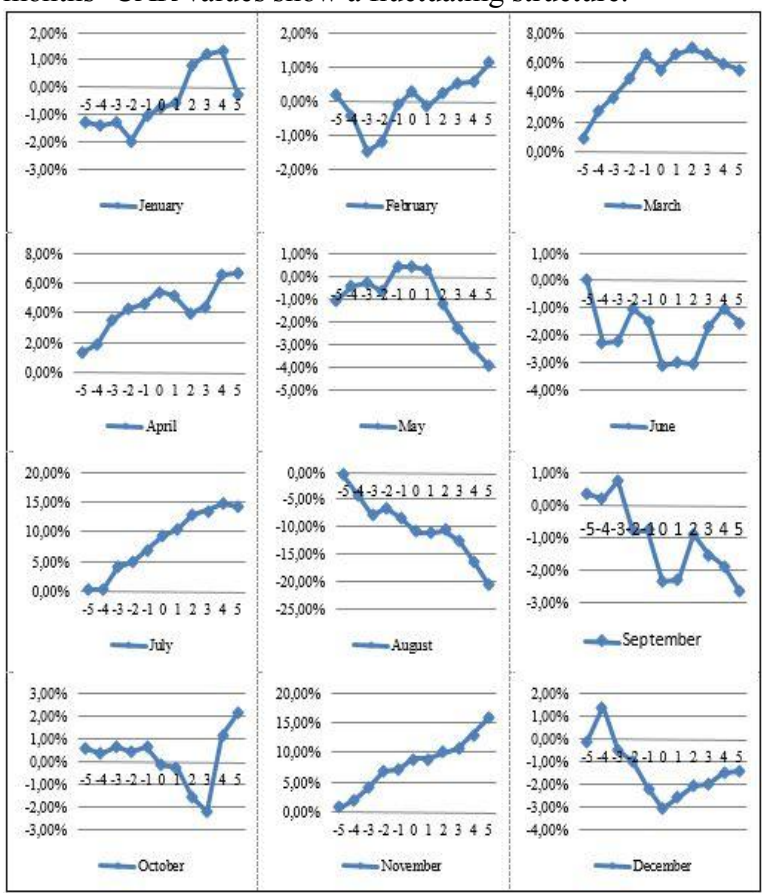

Figure 1. Cumulative Abnormal Returns (CAR) Graphs (2008)

Source: Figure complied by authors
Table 3 shows the results of Cumulative Abnormal Returns (CAR) during the testing period in 2012. Overall CAR values are positive on the event window $(-5,+5)$ only in March. The CAR values are completely negative in February and August. CAR values of the other months contain both positive and negative coefficients.

Table 3: Cumulative Abnormal Returns (CAR) During the Testing Period (2012)

\begin{tabular}{|c|c|c|c|c|c|c|}
\hline $\begin{array}{c}\text { Event } \\
\text { Wind } \\
\text { ow }\end{array}$ & $\begin{array}{c}\text { Januar } \\
\mathbf{y}\end{array}$ & $\begin{array}{c}\text { Februar } \\
\mathbf{y}\end{array}$ & March & April & May & June \\
\hline-5 & $-0,51 \%$ & $-3,96 \%$ & $7,37 \%$ & $0,69 \%$ & $1,86 \%$ & $-0,29 \%$ \\
\hline-4 & $0,29 \%$ & $-8,26 \%$ & $15,22 \%$ & $1,12 \%$ & $1,37 \%$ & $-0,30 \%$ \\
\hline-3 & $1,33 \%$ & $-12,05 \%$ & $22,78 \%$ & $-0,48 \%$ & $1,35 \%$ & $-1,30 \%$ \\
\hline-2 & $0,98 \%$ & $-15,89 \%$ & $30,16 \%$ & $0,32 \%$ & $-0,44 \%$ & $-0,91 \%$ \\
\hline-1 & $1,24 \%$ & $-19,25 \%$ & $37,15 \%$ & $0,36 \%$ & $-1,62 \%$ & $-0,93 \%$ \\
\hline 0 & $0,30 \%$ & $-21,46 \%$ & $44,83 \%$ & $-0,75 \%$ & $-0,37 \%$ & $-0,34 \%$ \\
\hline 1 & $0,28 \%$ & $-25,99 \%$ & $52,79 \%$ & $-1,67 \%$ & $-1,40 \%$ & $-0,18 \%$ \\
\hline 2 & $0,86 \%$ & $-31,23 \%$ & $59,87 \%$ & $-1,77 \%$ & $-2,14 \%$ & $-1,92 \%$ \\
\hline 3 & $0,68 \%$ & $-35,93 \%$ & $67,07 \%$ & $-2,82 \%$ & $-1,95 \%$ & $-1,87 \%$ \\
\hline 4 & $0,49 \%$ & $-39,55 \%$ & $75,32 \%$ & $-1,92 \%$ & $-1,54 \%$ & $-1,40 \%$ \\
\hline 5 & $0,90 \%$ & $-43,94 \%$ & $83,37 \%$ & $-1,52 \%$ & $-1,65 \%$ & $-1,82 \%$ \\
\hline $\begin{array}{c}\text { Event } \\
\text { Wind } \\
\text { ow }\end{array}$ & July & August & $\begin{array}{c}\text { Septem } \\
\text { ber }\end{array}$ & $\begin{array}{c}\text { Octobe } \\
\mathbf{r}\end{array}$ & $\begin{array}{c}\text { Novem } \\
\text { ber }\end{array}$ & $\begin{array}{c}\text { Decem } \\
\text { ber }\end{array}$ \\
\hline-5 & $0,24 \%$ & $-0,42 \%$ & $-0,14 \%$ & $-0,48 \%$ & $0,00 \%$ & $0,16 \%$ \\
\hline-4 & $0,26 \%$ & $-0,30 \%$ & $-0,37 \%$ & $-0,73 \%$ & $0,30 \%$ & $-0,61 \%$ \\
\hline-3 & $-0,13 \%$ & $-0,33 \%$ & $-0,27 \%$ & $-1,05 \%$ & $0,61 \%$ & $-0,68 \%$ \\
\hline-2 & $-0,84 \%$ & $-0,11 \%$ & $0,48 \%$ & $-1,25 \%$ & $-0,23 \%$ & $-0,94 \%$ \\
\hline-1 & $-1,42 \%$ & $-0,08 \%$ & $0,20 \%$ & $-1,45 \%$ & $-0,31 \%$ & $-1,59 \%$ \\
\hline 0 & $-1,15 \%$ & $-0,64 \%$ & $-0,24 \%$ & $-0,87 \%$ & $0,51 \%$ & $-1,88 \%$ \\
\hline 1 & $-1,41 \%$ & $-0,80 \%$ & $0,06 \%$ & $-1,46 \%$ & $1,59 \%$ & $-2,29 \%$ \\
\hline 2 & $-1,89 \%$ & $-0,69 \%$ & $-0,25 \%$ & $-1,06 \%$ & $1,48 \%$ & $-3,39 \%$ \\
\hline 3 & $-1,21 \%$ & $-0,65 \%$ & $0,32 \%$ & $-0,61 \%$ & $2,36 \%$ & $-2,94 \%$ \\
\hline 4 & $-0,46 \%$ & $-0,61 \%$ & $0,33 \%$ & $-0,42 \%$ & $2,69 \%$ & $-0,93 \%$ \\
\hline 5 & $-0,70 \%$ & $-0,77 \%$ & $-0,17 \%$ & $-1,46 \%$ & $2,41 \%$ & $-0,09 \%$ \\
\hline
\end{tabular}

Source: Table complied by authors

Figure 2 represents the graphs of Cumulative Abnormal Returns (CAR) in 2012. Cumulative abnormal returns generally do not continuously decrease or increase before or after the event days except in February and in March. CAR values steadily decrease before and after the event day only in February. On the other hand, CAR values steadily increase before and after the event day only in March. The CAR values of the other months show a fluctuating structure. 

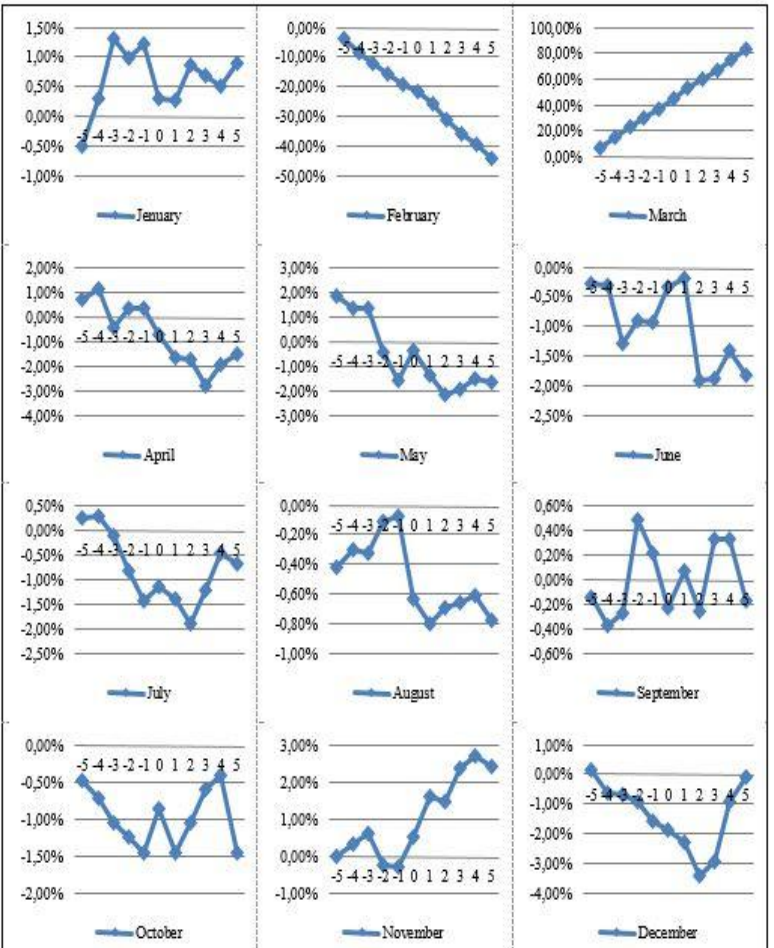

Figure 2. Cumulative Abnormal Returns (CAR) Graphs (2012)

Source: Figure complied by authors

Table 4 presents the t-statistics of CAR values. Firstly, in 2008 CAR $(-5,+5)$ value is positive and statistically significant for March, April, July and November. On the other hand, CAR $(-5,+5)$ value is negative and statistically significant for May, June, August, September and December for ten days event window around the decision of the Monetary Policy Committee. Since we reject the null, we conclude that the decision of the Monetary Policy Committee have impact on stock prices of deposit banks listed in Borsa Istanbul and investors can get positive or negative abnormal returns among the days of event window. For the other months, CAR value is not statistically significant. Hence, we can report that the CAR value is not significantly different from zero for January, February and October.

Secondly, in 2012 CAR $(-5,+5)$ value is positive and statistically significant for January, March and November. On the other hand, CAR $(-5,+5)$ value is negative and statistically significant for February, April, June, July, August, October and December for ten days event window around the decision of the Monetary Policy Committee. So, the null hypothesis is rejected for these months. CAR value is not statistically significant for the other months. Therefore, the decisions of the Monetary Policy Committee for these months have no impact on stock prices. When we compare the CAR values for 2008 and 2012, we report that CARs are positive in March and in November for both of the years. In addition, CARs are negative in June, August and December for both of the years.
Table 4: t-statistics for CAR Values

\begin{tabular}{|c|c|c|c|c|}
\hline \multirow{2}{*}{ Moar } & \multicolumn{2}{|c|}{2008} & \multicolumn{2}{|c|}{2012} \\
\hline & t-stat. & p value (sig.) & t-stat. & p value (sig.) \\
\hline January & $-1,421$ & 0,186 & $3,911^{* * *}$ & 0,003 \\
\hline February & $-0,219$ & 0,831 & $-5,918^{* * *}$ & 0,000 \\
\hline March & $8,760^{* * * *}$ & 0,000 & $5,987^{* * *}$ & 0,000 \\
\hline April & $8,537^{* * *}$ & 0,000 & $-2,001^{*}$ & 0,073 \\
\hline May & $-2,477^{* *}$ & 0,033 & $-1,342$ & 0,209 \\
\hline June & $-6,182^{* * *}$ & 0,000 & $-4,980^{* * *}$ & 0,001 \\
\hline July & $5,111^{* * *}$ & 0,000 & $-3,708^{* * *}$ & 0,004 \\
\hline August & $-6,003^{* * *}$ & 0,000 & $-6,356^{* * *}$ & 0,000 \\
\hline September & $-3,089^{* *}$ & 0,011 &,- 047 & 0,964 \\
\hline October & 0,377 & 0,714 & $-8,344^{* * *}$ & 0,000 \\
\hline November & $5,829^{* * *}$ & 0,000 & $3,089^{* *}$ & 0,011 \\
\hline December & $-3,638^{* * *}$ & 0,005 & $-3,999^{* * *}$ & 0,003 \\
\hline
\end{tabular}

\section{Source: Table complied by authors}

$$
\begin{gathered}
\text { Note: ***, ** and * indicate significant at } 1 \%, 5 \% \text { and } \\
10 \% \text { levels respectively. }
\end{gathered}
$$

\section{Conclusion}

In this study, we investigate whether the decisions of the Monetary Policy Committee have an impact on stock returns of deposit banks listed in BIST by using the event study methodology. We test this relation for the year 2008 as the global financial crisis period and for 2012. The average abnormal returns (AR) and cumulative abnormal returns (CAR) are calculated. Although there are many studies using the event study methodology, there is no study that focuses on whether the decisions of the Monetary Policy Committee have an impact on stock returns of Turkish deposit banks listed in BIST by using the event study method in literature. In this aspect, we believe our study will contribute to finance literature.

The results of this study show that the decisions of the Monetary Policy Committee for both 2008 as a global financial crisis year and 2012 as the other year (and a year in which new monetary policy rules are applied) have impact on stock prices of Turkish deposit banks listed in Borsa Istanbul in March, April, June, July, August, November and December. For 2008, CAR value is positive and statistically significant for March, April, July and November, negative and statistically significant for May, June, August, September and December for the ten days event window surrounding the decision of the Monetary Policy Committee. For 2012, CAR value is positive and statistically significant for January, March and November, negative and statistically significant for February, April, June, July, August, October and December. So, investors can get positive or negative abnormal returns among the days of event window in these months.

Consequently, we can conclude that Turkish deposit banks listed in Borsa Istanbul give inconsistent results 
with efficient-market hypothesis for 2008 and 2012. Both in the crisis year and in a year with the new monetary policy environment, the market is not in a semi-strong efficient form. Monetary policy decisions have an impact on the banks' return both in 2008 and in 2012

\section{REFERENCES}

Aktaş, Z., Alp, H., Gürkaynak, R., Kesriyeli, M. \& Orak, M. (2009). Türkiye'de Para Politikasının Aktarımı: Para Politikasının Mali Piyasalara Etkisi. İktisat, İşletme ve Finans, 24 (278), 924.

Andersson, M. (2010). Using Intraday Data to Gauge Financial Market Responses to Federal Reserve and ECB Monetary Policy Decisions. International Journal of Central Banking, 6(2), 117-145.

Bernanke, B., \& Kuttner, K. (2005). What Explains the Stock Market's Reaction to Federal Reserve Policy? Journal of Finance, 60 (3), 1221-1257.

Bohl, M.T., Siklos, P.L. \& Sondermann, D. (2008). European Stock Markets and the ECB's Monetary Policy Surprises. International Finance, 11 (2), 117-130.

Bomfim, A. (2003). Pre-announcement Effects, News Effects and Volatility: Monetary Policy and The Stock Market. Journal of Banking and Finance, 27 (1), 133151.

Chulia, H., Martens, M. \& Dijk, D. (2010). Asymmetric Effects of Federal Funds Target Rate Changes on S\&P100 Stock Returns, Volatilities and Correlations. Journal of Banking and Finance, 34 (4), 834-839.

Demiralp, S. \& Y1lmaz, K. (2010). Para Politikas1 Beklentilerinin Sermaye Piyasaları Üzerindeki Etkisi. TÜSİADKOÇ University Economic Research Forum Working Paper Series. No:1008

Duran, M., Özcan, G., Özlü, P. \& Ünalmış, D. (2012). Measuring the Impact of Monetary Policy on Asset Prices in Turkey. Economics Letters, 114, 29-31.

Ehrmann, M. \& M. Fratzscher (2004). Taking Stock: Monetary Policy Transmission to Equity Markets. European Central Bank Working Paper Series, No: 354.

Ehrmann, M., Fratzscher, M. \& Rigobon, R. (2005). Stocks, Bonds, Money Markets and Exchange Rates: Measuring International Financial Transmission. NBER Working Paper Series No:11166.

Fama, F. (1970). Efficient Capital Markets: A Review of Theory and Empirical Work. The Journal of Finance, 25 (2), 383417.

Farka, M. (2009). The Effect of Monetary Policy Shocks on Stock Prices Accounting for Endogeneity and Omitted Variable Biases. Review of Financial Economics, 18, 47-55.

Hussain, S. M. (2011). Simultaneous Monetary Policy Announcements and International Stock Markets Response: An Intraday Analysis. Journal of Banking \& Finance, 35 (3), 752-764.

Ibicioglu, M. \& Kapusuzoglu, A. (2012). An Empirical Analysis of Impact of Central Bank Policy Interest Rate on the Decisions of Share Investors: Evidence from Turkey. Procedia Social and Behavioral Sciences, 62, $489-493$

Jensen,G.R.，Johnson,R.R.， \& Mercer，J.M. (1996). Business Conditions, Monetary Policy, and Expected Security Returns. Journal of Financial Economics, 40, 213-37.

Karan, Mehmet B. (2003). Yatırım Analizi ve Portföy Yönetimi. Gazi Kitabevi, Ankara.

Kholodilin, K., Montagnoli, A., Napolitano, O. \& Siliverstovs, B., 2009. Assessing the Impact of the ECB's Monetary Policy on the Stock Markets: A Sectoral View. Economics Letters, 105, 211213.

Kucukkocaoglu, G., Unalmis, D. \& Unalmis, I. (2013). How Do Banks' Stock Returns Respond to Monetary Policy Committee Announcements in Turkey? Evidence from Traditional versus New 
Monetary Policy Episodes. Central Bank of the Republic of Turkey Working Paper, No: 13/30

Patelis, A. D. (1997). Stock Return Predictability and the Role of Monetary Policy. Journal of Finance, 52 (5), 1951-72.

Rigobon, R., \& Sack, B. (2003). Measuring the Reaction of Monetary Policy to the Stock Market. Quarterly Journal of Economics, 118, 639-70.

Rigobon, R. \& B. Sack (2004). The Impact of Monetary Policy on Asset Prices. Journal of Monetary Economics, 51(8), 1553-1575.

Scharler, J. (2008). Bank Lending and the Stock Market's Response to Monetary Policy Shocks. International Review of Economics and Finance, 17 (3), 425435.

Soylu, N., Korkmaz, T. \& Cevik, E.I. (2014). Merkez Bankası Faiz Duyurularının Finansal Piyasalara Etkisi. Business and Economics Research Journal, 5(4), 89-118. 